Article

\title{
Surface Oxidation Behavior and Wear Performance of a Fe-21.3Cr-3.5Al-0.5Ti-0.4Zr Steel
}

\author{
Jian An ${ }^{1,2, *}$, Yiguang Chen ${ }^{2}$, Zhihui Liu ${ }^{2}$ and Yuxi Tian ${ }^{2}$ \\ 1 Key Laboratory of Automobile Materials, Ministry of Education, Jilin University, Changchun 130025, China \\ 2 Department of Materials Science and Engineering, Jilin University, Changchun 130025, China; \\ Chenyg18@163.com (Y.C.); liuzhihui@jlu.edu.cn (Z.L.); tianyx18@yeah.net (Y.T.) \\ * Correspondence: anjian@jlu.edu.cn; Tel.: +86-431-85095876
}

Received: 11 July 2020; Accepted: 29 July 2020; Published: 1 August 2020

\begin{abstract}
A type of Fe-21.3Cr-3.5Al-0.5Ti-0.4Zr steel was produced for application of spot-welding location pins in automobile industry. The oxidation behavior at temperatures of $1220-1340{ }^{\circ} \mathrm{C}$ and wear performance were investigated. The morphologies and constituent phases of the oxide layers were characterized by scanning electron microscope (SEM) and X-ray diffractometer (XRD). The hardness and wear performance of the oxide layers were also measured. The results showed that the mass gain presented a stage characteristic with increasing temperature, i.e., a small increasing at $1220-1260{ }^{\circ} \mathrm{C}$, a moderate increasing at $1280-1300{ }^{\circ} \mathrm{C}$, and a great increasing at $1320-1340{ }^{\circ} \mathrm{C}$. The oxide layer primarily consisted of $\mathrm{Al}_{2} \mathrm{O}_{3}$ phase and a small amount of $\mathrm{ZrO}_{2}$ phase. $\mathrm{ZrO}_{2}$ increased in amount with temperature rising from 1220 to $1340{ }^{\circ} \mathrm{C}$. The oxidized surface exhibited an increase of hardness with increasing temperature, but the lowest wear loss occurred at the oxidation temperature of $1280^{\circ} \mathrm{C}$.
\end{abstract}

Keywords: Fe-Cr-Al-Ti-Zr steel; oxidation behavior; $\mathrm{Al}_{2} \mathrm{O}_{3}$; hardness; wear

\section{Introduction}

Fe-Cr-Al based alloys are well known for its excellent oxidation resistance and applications for fabrication of high-temperature components-such as electric resistance for furnaces, furnace tubes, fiber based domestic and industrial burners, and metallic substrate of automotive catalytic converters [1-5]. Two major types of protective oxide-i.e., chromium oxide and aluminum oxide-can form on the surfaces of Fe-Cr-Al based alloys in different temperature ranges. $\mathrm{Cr}_{2} \mathrm{O}_{3}$ can only provide good corrosion protection at low and intermediate temperatures, while $\mathrm{Al}_{2} \mathrm{O}_{3}$ can offer better corrosion protection at high temperatures. The most often reported upper limits of temperatures allowing the protective scales to form and sustain are $900-1100{ }^{\circ} \mathrm{C}$ for $\mathrm{Cr}_{2} \mathrm{O}_{3}$ and $1200-1400{ }^{\circ} \mathrm{C}$ for $\mathrm{Al}_{2} \mathrm{O}_{3}$ [6-10]. The better oxidation resistance of $\mathrm{Fe}-\mathrm{Cr}-\mathrm{Al}$ alloys at high temperatures is attributed to the formation of an adherent and slow-growing $\alpha$-alumina layer. The role of $\mathrm{Cr}$ addition to $\mathrm{Fe}-\mathrm{Al}$ alloys acts as a so-called third element effect [11,12]. That is, it promotes formation of $\mathrm{Al}_{2} \mathrm{O}_{3}$ on the Fe-Cr-Al alloys under a lower content than that in binary Fe-Al alloys. The effects of alloying elements on the physical properties and corrosion resistance of $\mathrm{Fe}-\mathrm{Cr}-\mathrm{Al}$ alloys have been investigated quite thoroughly [13-15]. However, it is less noticeable that $\mathrm{Al}_{2} \mathrm{O}_{3}$-rich oxide layer also possesses high hardness and good insulating properties, therefore, another application for certain types of $\mathrm{Fe}-\mathrm{Cr}-\mathrm{Al}$ alloys is to make spot welding location pins in automobile industry. The excellent oxidation resistance, a certain thickness of about 5-10 $\mu \mathrm{m} \mathrm{Al}_{2} \mathrm{O}_{3}$ layer with good electrical insulation, and high wear resistance are required since the spot welding location pins suffered from a high environment temperature of $1000-1200{ }^{\circ} \mathrm{C}$ and tens thousands times of repeated wear during the welding location process. 
The material currently used for making spot welding location pins is a special Fe-Cr-Al alloy containing some trace elements, i.e., the so-called KCF material. This material is costly and its exact composition is unknown. Therefore, it is of interest to develop a cheap material as an alternative to $\mathrm{KCF}$ material. It is known that the addition of reactive elements such as $\mathrm{Zr}$ and Ti to Fe-Cr-Al alloy improve the oxide scale adhesion [16]. For the purpose of preparing a material for making spot welding location pins, a type of Fe-21.3Cr-3.5Al-0.5Ti-0.4Zr steel was designed to satisfy the requirements for oxidation resistance, electrical insulation, and wear resistance. In addition, the material was a single-phase alloy with very low content of carbon, and has good rolling properties.

In the present study, Fe-21.3Cr-3.5Al-0.5Ti-0.4Zr steel was fabricated for application of spot welding location pins. Oxidation behavior of the alloy was studied at temperatures of $1220-1340{ }^{\circ} \mathrm{C}$. The hardness and wear performance of samples oxidized at different oxidation temperatures were also measured and analyzed.

\section{Experimental Details}

The studied material was a Fe-Cr-Al-Ti-Zr steel prepared using pure Fe (99.98 wt \%), $\mathrm{Al}(99.9 \mathrm{wt} \%)$, Cr (99.9 wt \%), Ti (99.9 wt \%), Zr (99.9 wt \%), and Ni (99.9 wt \%) by means of vacuum induction melting. The cast ingot was hot-rolled into bars of $20 \mathrm{~mm}$ in diameter at $1100{ }^{\circ} \mathrm{C}$. The chemical composition of the alloy was analyzed by chemical analysis, as listed in Table 1.

Table 1. Chemical composition of studied alloy (wt \%).

\begin{tabular}{cccccccccc}
\hline $\mathbf{C}$ & $\mathbf{C r}$ & $\mathbf{A l}$ & $\mathbf{S i}$ & $\mathbf{M n}$ & $\mathbf{N i}$ & $\mathbf{T i}$ & $\mathbf{Z r}$ & $\mathbf{S}$ & $\mathbf{P}$ \\
\hline 0.015 & 21.27 & 3.50 & 0.10 & 0.24 & 0.24 & 0.53 & 0.42 & 0.0037 & 0.0090 \\
\hline
\end{tabular}

Cylindrical samples with dimensions of $12 \mathrm{~mm}$ in diameter and $20 \mathrm{~mm}$ in length were machined from the bars for oxidation testing. The end surfaces of samples were ground with 1000 grit SiC abrasive paper, and then polished to surface roughness of about $0.4 \mu \mathrm{m} \mathrm{Ra}$. Oxidation tests were performed in air at various temperatures of $1200-1340{ }^{\circ} \mathrm{C}$ for $3 \mathrm{~h}$ in a resistance furnace. The mass gain was measured on a single pan electrical balance with an accuracy of $0.1 \mathrm{mg}$. Each mass gain was an average of three samples. Surface oxide layers were examined by a Rigaku D/MAX 2500PC X-ray diffractometer (XRD, Rigaku Corporation, Japan.). The morphologies and chemical compositions of oxidized surfaces were observed using a TESCAN VEGA3 scanning electron microscope (SEM, TEsCAN, Germany) equipped with an energy dispersive $X$-ray spectrometer (EDS). The hardness of oxidized surfaces was measured using a HVS-1000 type digital microhardness tester (Lunjie Electromechanical Instrument Co., Ltd, Shanghai, China) with a load of $0.098 \mathrm{~N}$ and a holding time of $20 \mathrm{~s}$. Wear testing was performed at the sliding speed of $1.0 \mathrm{~m} / \mathrm{s}$ under the load of $20 \mathrm{~N}$ for a sliding distance of $188.4 \mathrm{~m}$ (1000 rotations) on a MG2000 pin-on-disc tribometer (Zhangjiakou Chengxin Test Equipment Manufacturing Co., Ltd., Zhangjiakou, China). Cylindrical pins were machined from bars into dimensions of $6 \mathrm{~mm}$ in diameter and $12 \mathrm{~mm}$ in length. After end surface preparation of pins including polishing to a roughness of about $0.4 \mu \mathrm{m} R \mathrm{Ra}$ and cleaning in methanol solution, the pins were oxidized at temperatures of $1200-1340{ }^{\circ} \mathrm{C}$. The counter discs of $70 \mathrm{~mm}$ in diameter and $10 \mathrm{~mm}$ in thickness were made of AISI 5150 steel with hardness of 57 HRC. The wear track of the discs was $60 \mathrm{~mm}$ in diameter. The surfaces of discs were also polished to a roughness of about $0.4 \mu \mathrm{m}$ Ra before wear testing. The wear resistance of oxide layers formed at various temperatures was characterized by weight loss. Each weight loss in the study was an average of three samples. The morphologies of worn surfaces of pins were examined using SEM and EDS.

\section{Results and Discussions}

\subsection{Microstructure of Fe-21.3Cr-3.5Al-0.5Ti-0.4Zr Steel}

The microstructure of Fe-21.3Cr-3.5Al-0.5Ti-0.4Zr alloy primarily consisted of equiaxed grains with average size of about $21 \mu \mathrm{m}$, as shown in Figure 1a. XRD analysis shown in Figure 1b identified 
only the presence of $\alpha$-Fe phase. Therefore, Fe-21.3Cr-3.5Al-0.5Ti- $0.4 \mathrm{Zr}$ steel can be considered as a single-phase alloy.

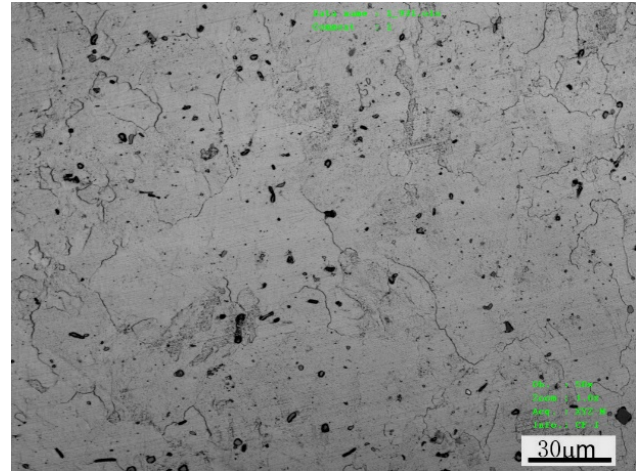

(a)

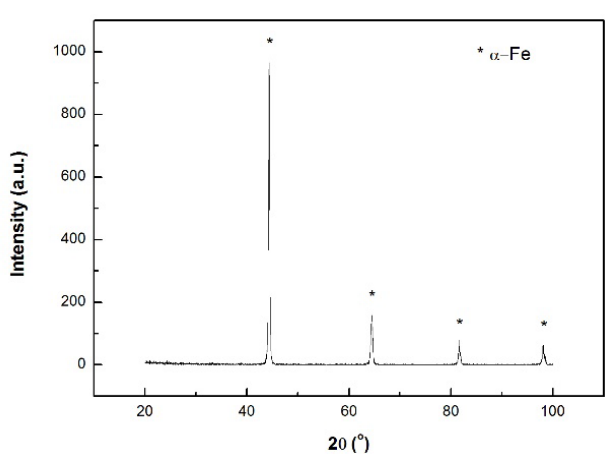

(b)

Figure 1. Optical microstructure (a) and X-ray diffraction (XRD) spectrum (b) of Fe-21.3Cr-3.5Al-0.5Ti$0.4 \mathrm{Zr}$ steel.

\subsection{Oxidation Behavior}

Figure 2 shows the mass gain of Fe-21.3Cr-3.5Al-0.5Ti-0.4Zr steel at temperatures of $1220-1340{ }^{\circ} \mathrm{C}$. The mass gain rose with temperature in general, presenting a three-stage characteristic. The first stage ranged from 1220 to $1260{ }^{\circ} \mathrm{C}$, where the mass gain only increased a little, varying from 2.23 to $2.94 \mathrm{mg} / \mathrm{cm}^{2}$. The second stage ranged from 1280 to $1300^{\circ} \mathrm{C}$, where the mass gain increased moderately and maintained a plateau, varying from 3.70 to $4.38 \mathrm{mg} / \mathrm{cm}^{2}$. The third stage ranged from 1320 to $1340{ }^{\circ} \mathrm{C}$, where the mass gain increased considerably and reached the highest level of $6.22 \mathrm{mg} / \mathrm{cm}^{2}$ at $1340{ }^{\circ} \mathrm{C}$. It is also noted that mass gain decreases a little at $1260{ }^{\circ} \mathrm{C}$ after rising at $1240{ }^{\circ} \mathrm{C}$ in the first stage, and also decreased slightly at $1300^{\circ} \mathrm{C}$ after rising at $1280^{\circ} \mathrm{C}$ in second stage.

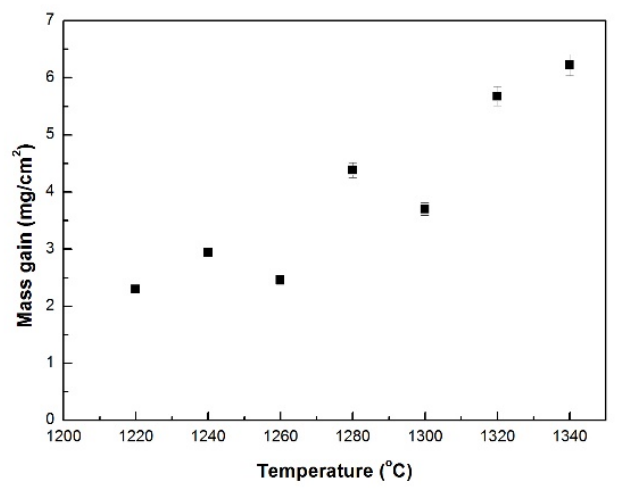

Figure 2. Mass gain at temperatures of $1220-1340{ }^{\circ} \mathrm{C}$ for $3 \mathrm{~h}$.

\subsection{Phase Constituents and Morphologies of Oxide Layers}

The $X R D$ patterns of oxidation surfaces at various temperatures are shown in Figure 3. At $1220^{\circ} \mathrm{C}$, the XRD peaks of $\mathrm{Al}_{2} \mathrm{O}_{3}$ and $\mathrm{ZrO}_{2}$ were observed besides the XRD peaks of $\alpha$-Fe substrate (Figure $3 \mathrm{a}$ ). The XRD peaks of $\mathrm{ZrO}_{2}$ presented a quite lower intensity as compared with the peaks of $\mathrm{Al}_{2} \mathrm{O}_{3}$. It suggests that the oxide layer mainly consists of $\mathrm{Al}_{2} \mathrm{O}_{3}$ phase. At the temperatures of 1240 and $1260{ }^{\circ} \mathrm{C}$, the XRD pattern almost remained unchanged (Figure $3 b$ ). This means that the oxide layer varies little in constituent phase amount and thickness. At the temperatures of 1280 and $1300{ }^{\circ} \mathrm{C}$, the intensity of peaks of $\mathrm{Al}_{2} \mathrm{O}_{3}$ and $\mathrm{ZrO}_{2}$ started enhancing, especially at $1300{ }^{\circ} \mathrm{C}$ (Figure $3 c, d$ ). This indicates that the amount of $\mathrm{Al}_{2} \mathrm{O}_{3}$ and $\mathrm{ZrO}_{2}$ increases significantly in the oxide layer. At $1320{ }^{\circ} \mathrm{C}$, the peak of $\mathrm{Al}_{2} \mathrm{O}_{3}$ at $35^{\circ}$ was the highest intensified and surpassed the peaks of other phases such as $\alpha$-Fe substrate and 
$\mathrm{ZrO}_{2}$ (Figure 3e), suggesting that $\mathrm{Al}_{2} \mathrm{O}_{3}$ grew rapidly and the oxide layer considerably thickened. However, at $1340{ }^{\circ} \mathrm{C}$, it was found that the peak of $\alpha$-Fe at $44.38^{\circ}$ suddenly increased again (Figure 3f). It is thought to be due to formation of incompact blocks of magnetite phase (containing $\mathrm{Fe}_{2} \mathrm{Fe}_{2} \mathrm{O}$, and $\mathrm{Fe}_{3} \mathrm{O}_{4}$ ) in the oxide layer, which was later observed from elemental mappings of the oxidized surface. The surface morphologies after oxidation at different temperatures are shown in Figure 4. The EDS chemical compositions of oxidation surfaces at different temperatures are listed in Table 2. At temperatures of $1220-1260{ }^{\circ} \mathrm{C}$, the oxide layer mainly consisted of fine equiaxed grains (Figure 4a,b). EDS analysis revealed that the content of $\mathrm{Al}$ element ranged from $41.28 \%$ to $42.7 \%$, and the content of O element ranged from $47.89 \%$ to $48.13 .7 \%$. It indicates that surface oxide layers are mainly composed of $\mathrm{Al}_{2} \mathrm{O}_{3}$ grains. In addition, at $1220^{\circ} \mathrm{C}$, a few large particles were found to be formed on the surface, which was identified as particles containing $\mathrm{Zr}$ and P elements by EDS elemental mapping. This type of particles decreased in amount with increasing temperature, and almost disappeared at $1260^{\circ} \mathrm{C}$, which may be responsible for a little decrease of mass gain at $1260{ }^{\circ} \mathrm{C}$. At temperatures of 1280 and $1300{ }^{\circ} \mathrm{C}$, the size of grains increased (observed from microphotograph at $4800 \times$ magnification, not shown here), and the oxide layers were more compact and more uniform in thickness as compared with the oxide layers formed at 1220 and $1260^{\circ} \mathrm{C}$ (Figure 4c,d). It is found that at $1300{ }^{\circ} \mathrm{C}$, the content of oxygen increased to a relatively high level of $48.70 \%$, and content of zirconium element also reached as high as $6.58 \%$, meanwhile the content of aluminum element decreased a little to $40.30 \%$, and the content of iron element decreased to a low level of $2.27 \%$. The more $\mathrm{ZrO}_{2}$ formed in the oxide layer could enhance the density, accordingly resulting in a little decrease of mass gain at $1300{ }^{\circ} \mathrm{C}$. At temperatures of 1320 and $1340{ }^{\circ} \mathrm{C}$, the grains grew significantly (Figure $4 \mathrm{e}, \mathrm{f}$ ). Meanwhile, the content of zirconium increased to a high level of 7.75-8.73\%, suggesting formation of more fine $\mathrm{ZrO}_{2}$ particles in the oxide layer. At $1340{ }^{\circ} \mathrm{C}$, a few oxide polygonal particles grew abnormally at localized areas, which resulted in interstices at those localized areas. These particles were found to be rich in iron and oxygen elements by the elemental mappings, as shown in Figure 5. Therefore, these particles were identified to be magnetite as observed in XRD analysis result. Furthermore, because the polygonal magnetite blocks formed on the surface at $1340{ }^{\circ} \mathrm{C}$ resulted in interstices at localized area of the surface, the XRD analysis result in Figure $3 \mathrm{f}$ shows a high peak of $\alpha$-Fe substrate at $44^{\circ}$ again.

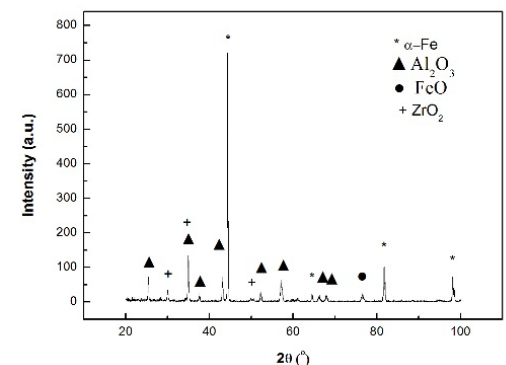

(a)

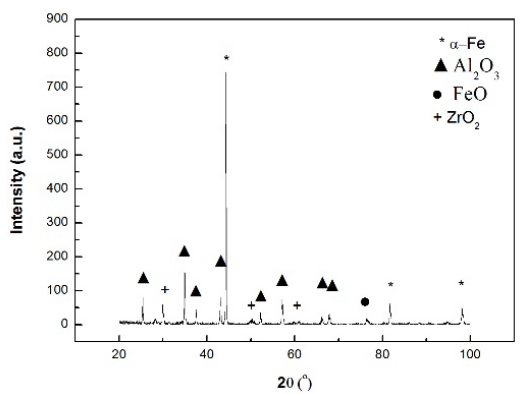

(c)

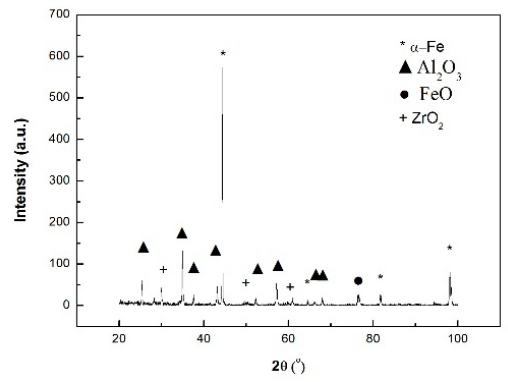

(b)

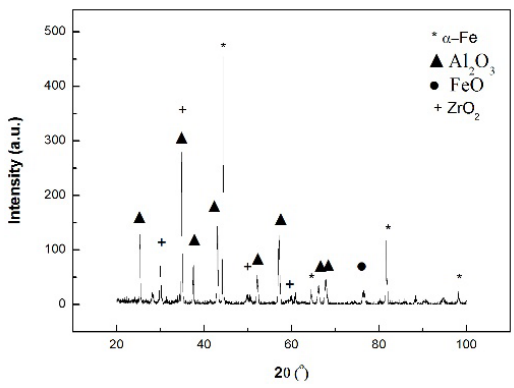

(d)

Figure 3. Cont. 


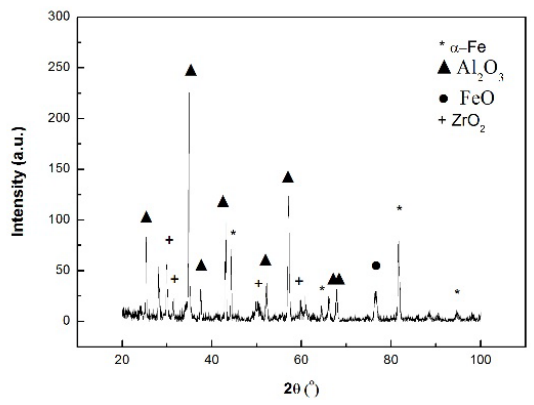

(e)

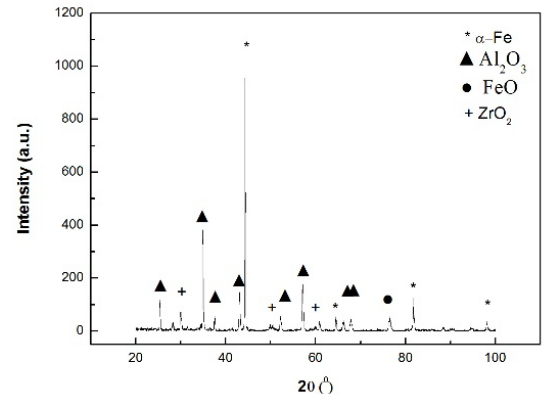

(f)

Figure 3. XRD patterns of oxide layers treated at different temperatures for $3 \mathrm{~h}$ : (a) $1220^{\circ} \mathrm{C}$, (b) $1260^{\circ} \mathrm{C}$, (c) $1280{ }^{\circ} \mathrm{C}$, (d) $1300{ }^{\circ} \mathrm{C}$, (e) $1320^{\circ} \mathrm{C}$, (f) $1340^{\circ} \mathrm{C}$.
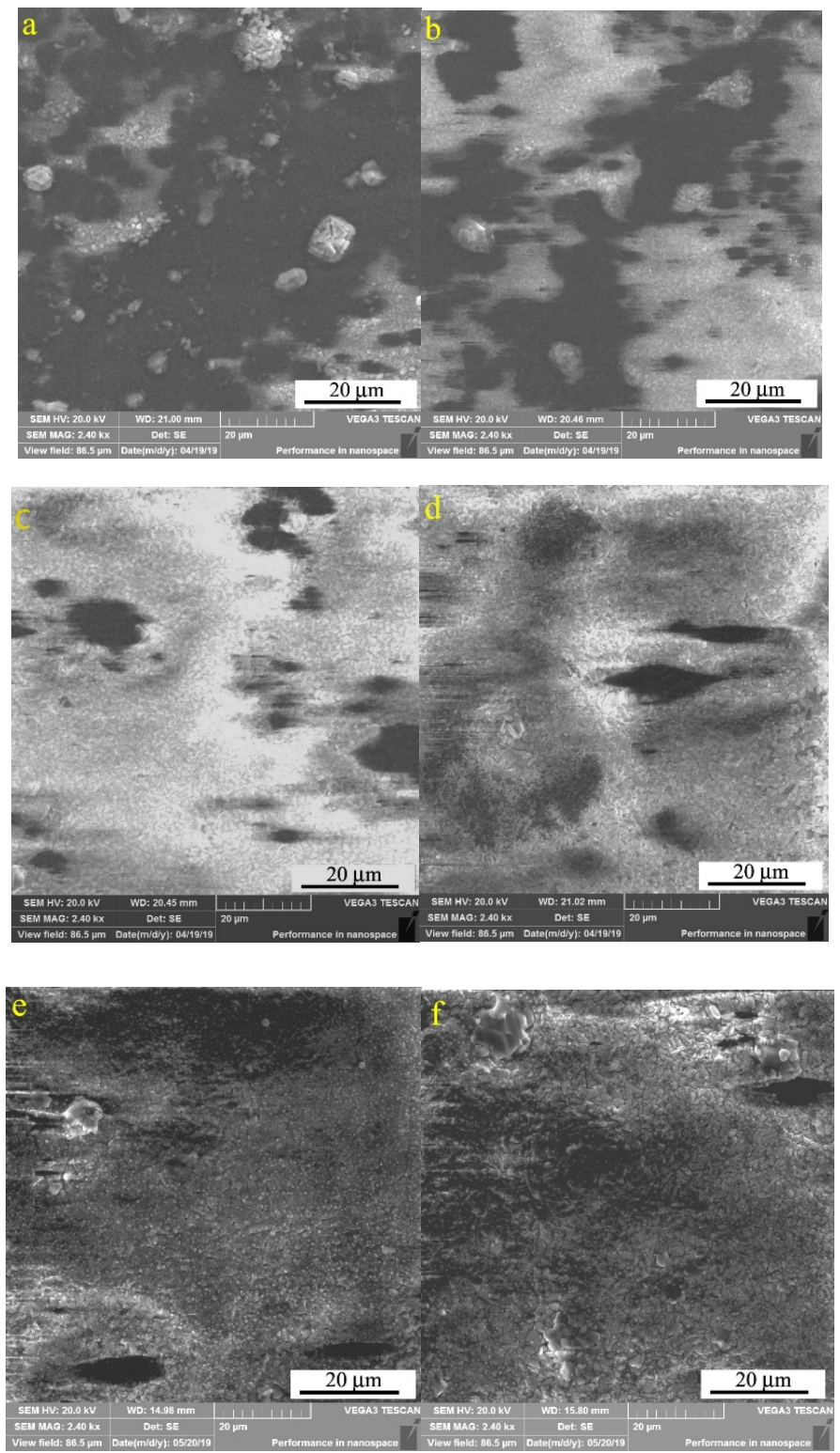

Figure 4. Surface morphologies of samples treated at different temperatures for $3 \mathrm{~h}$ : (a) $1220^{\circ} \mathrm{C}$, (b) $1260{ }^{\circ} \mathrm{C}$, (c) $1280{ }^{\circ} \mathrm{C}$, (d) $1300{ }^{\circ} \mathrm{C}$, (e) $1320^{\circ} \mathrm{C}$, (f) $1340{ }^{\circ} \mathrm{C}$. 
Table 2. Contents of major elements on surfaces of Fe-Cr-Al-Ti-Zr steel oxidized at different temperatures (wt \%).

\begin{tabular}{ccccccc}
\hline Temperature $\left({ }^{\circ} \mathbf{C}\right)$ & $\mathbf{O}$ & $\mathbf{A l}$ & $\mathbf{C r}$ & $\mathbf{Z r}$ & $\mathbf{T i}$ & $\mathbf{F e}$ \\
\hline 1220 & 47.95 & 41.28 & 2.78 & 3.32 & 0.37 & 4.07 \\
1240 & 47.89 & 41.75 & 1.11 & 4.51 & 0.19 & 2.87 \\
1260 & 48.13 & 42.70 & 1.34 & 4.95 & 0.28 & 2.38 \\
1280 & 48.60 & 40.64 & 1.59 & 5.77 & 0.18 & 3.11 \\
1300 & 48.70 & 40.30 & 1.47 & 6.58 & 0.24 & 2.27 \\
1320 & 47.92 & 39.60 & 1.22 & 7.75 & 0.27 & 3.24 \\
1340 & 49.85 & 36.09 & 1.69 & 8.73 & 0.41 & 3.23 \\
\hline
\end{tabular}
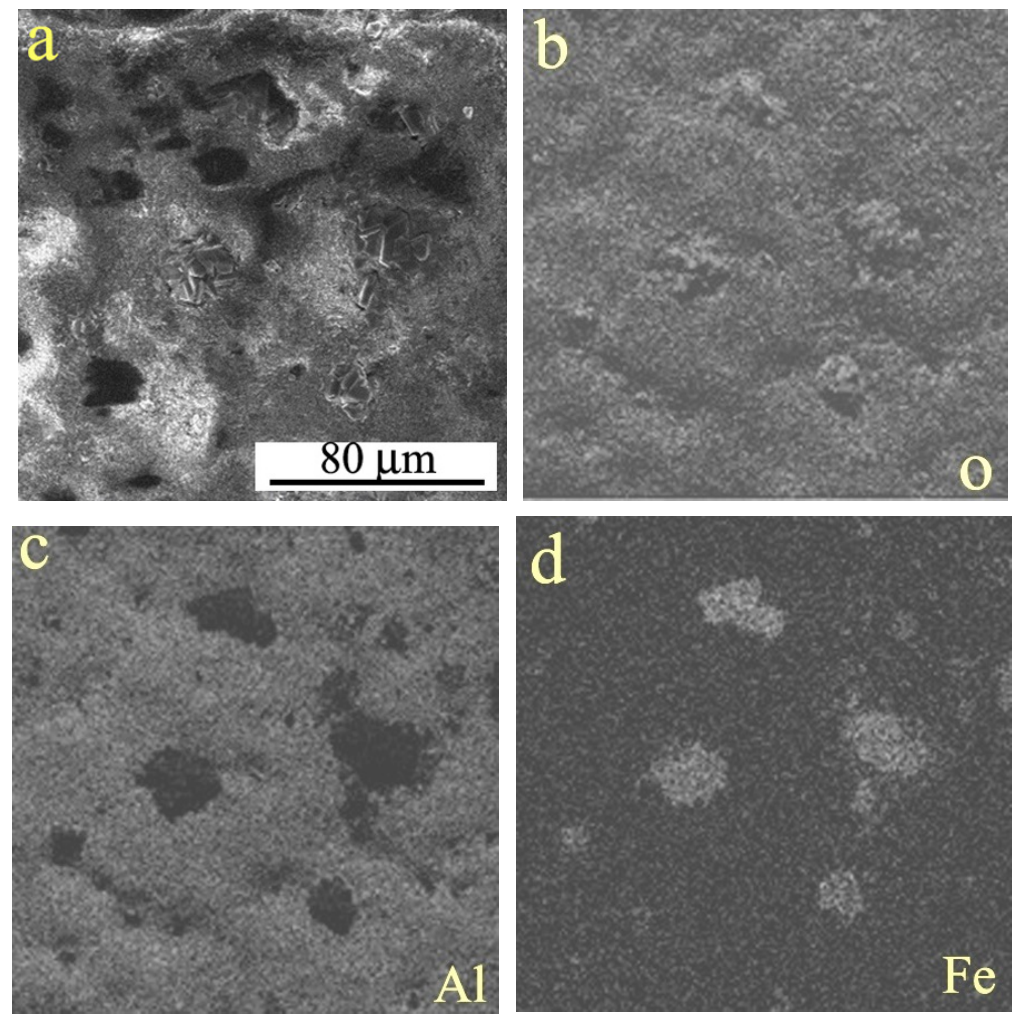

Figure 5. Scanning electron microscope (SEM) image and elemental mappings of surface oxidzed at $1340{ }^{\circ} \mathrm{C}$ for 3 h: (a) SEM image, (b) O, (c) Al, (d) Fe.

\subsection{Cross-Sectional Structures of Oxide Layers}

The cross-sectional structures of oxide layers formed at different temperatures were examined using SEM and EDS techniques. Since the oxide layers were not uniform in thickness, the minimum, maximum, and average thicknesses of oxide layers in field of view were measured by means of SEM observation as well as elemental mappings of $\mathrm{O}, \mathrm{Al}, \mathrm{Cr}, \mathrm{Zr}$, and $\mathrm{Fe}$, as listed in Table 3. It was found that at $1220^{\circ} \mathrm{C}$ and $1240{ }^{\circ} \mathrm{C}$, the oxide layers were quite uneven in thickness, the minimum and maximum thicknesses were $1.81 \mu \mathrm{m}$ and $15.45 \mu \mathrm{m}$ at $1220^{\circ} \mathrm{C}$, and $0.91 \mu \mathrm{m}$ and $9.09 \mu \mathrm{m}$ at $1240{ }^{\circ} \mathrm{C}$, respectively. With increasing temperature to high temperature such as $1260^{\circ} \mathrm{C}$ and $1280^{\circ} \mathrm{C}$, the difference between the maximum and minimum thickness decreased, and the average thickness increase to a range of 5.55-7.27 $\mu \mathrm{m}$. At a temperature of $1300{ }^{\circ} \mathrm{C}$, the oxide layer was uniform in thickness, but the average thickness decreased to about $6.46 \mu \mathrm{m}$. As temperature was increased to the highest level of $1320-1340{ }^{\circ} \mathrm{C}$, the average thickness increased again, however, the difference between the maximum and minimum thickness increased again. 
Table 3. Thickness of oxide layers of the Fe-Cr-Al-Ti-Zr steel oxidized at different temperatures for $3 \mathrm{~h}$.

\begin{tabular}{cccccccc}
\hline Temperature $\left({ }^{\circ} \mathbf{C}\right)$ & $\mathbf{1 2 2 0}$ & $\mathbf{1 2 4 0}$ & $\mathbf{1 2 6 0}$ & $\mathbf{1 2 8 0}$ & $\mathbf{1 3 0 0}$ & $\mathbf{1 3 2 0}$ & $\mathbf{1 3 4 0}$ \\
\hline Average thickness $(\mu \mathrm{m})$ & 6.54 & 5.01 & 5.55 & 7.27 & 6.46 & 7.31 & 7.63 \\
Minimum thickness $(\mu \mathrm{m})$ & 1.81 & 0.91 & 4.44 & 5.45 & 5.52 & 3.27 & 3.63 \\
Maximum thickness $(\mu \mathrm{m})$ & 15.45 & 9.09 & 7.77 & 11.26 & 7.45 & 14.54 & 12.72 \\
\hline
\end{tabular}

The cross-sectional microstructure observation and elemental mapping analysis of the oxide layer revealed that at 1220 and $1240{ }^{\circ} \mathrm{C}$, the oxide layers primarily consisted of $\mathrm{Al}_{2} \mathrm{O}_{3}$, since the oxygen elemental mapping of the oxide layer agreed well with the aluminum elemental mapping. When temperature was increased to $1260^{\circ} \mathrm{C}$, the cross-sectional structure of oxide layer was improved, namely the oxide layer appeared to be even in thickness although the average thickness was not increased significantly. In addition, it was found that the outmost part of oxide layer was rich in $\mathrm{Zr}$ element, as shown in Figure 6. At $1280{ }^{\circ} \mathrm{C}$, the thickness of oxide layer was further increased, and $\mathrm{Zr}$ element was uniformly distributed in almost entire oxide layer, as shown in Figure 7 . At $1300{ }^{\circ} \mathrm{C}$, the structure of oxide layer was similar to that at $1280^{\circ} \mathrm{C}$, but the average thickness of the oxide layer decreased a little. However, at high temperature of 1320 and $1340^{\circ} \mathrm{C}$, the density of the oxide layer decreased, there are porosity formed in the top part of oxide layer. Therefore, the oxide layer at $1280{ }^{\circ} \mathrm{C}$ is considered to be good in terms of thickness distribution, microstructure density, and distribution of phase constituents.
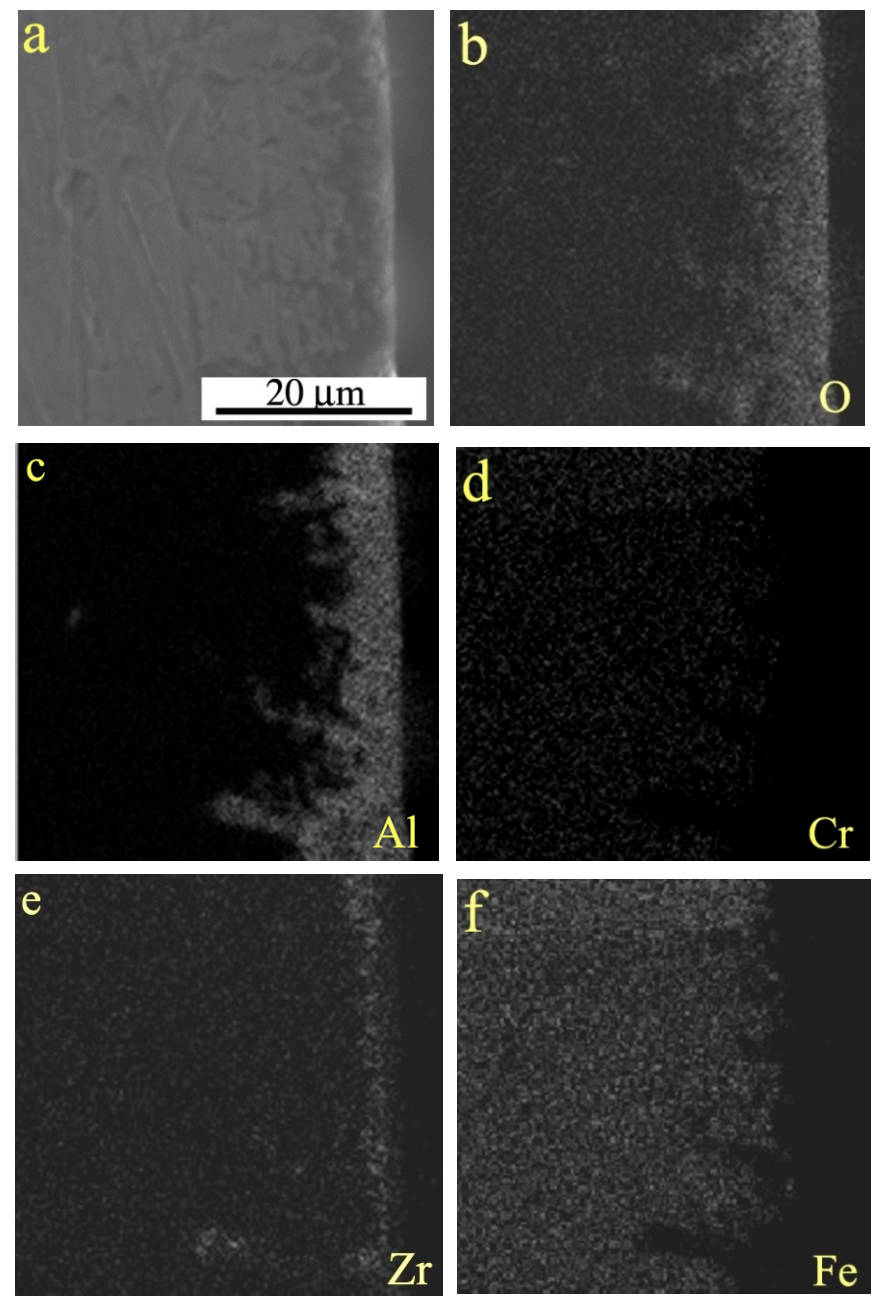

Figure 6. SEM image and elemental mappings of cross-sectional microstructure of sample oxidized at $1260{ }^{\circ} \mathrm{C}$ for $3 \mathrm{~h}$ : (a) SEM image, (b) O, (c) Al, (d) Cr, (e) Zr, (f) Fe. 

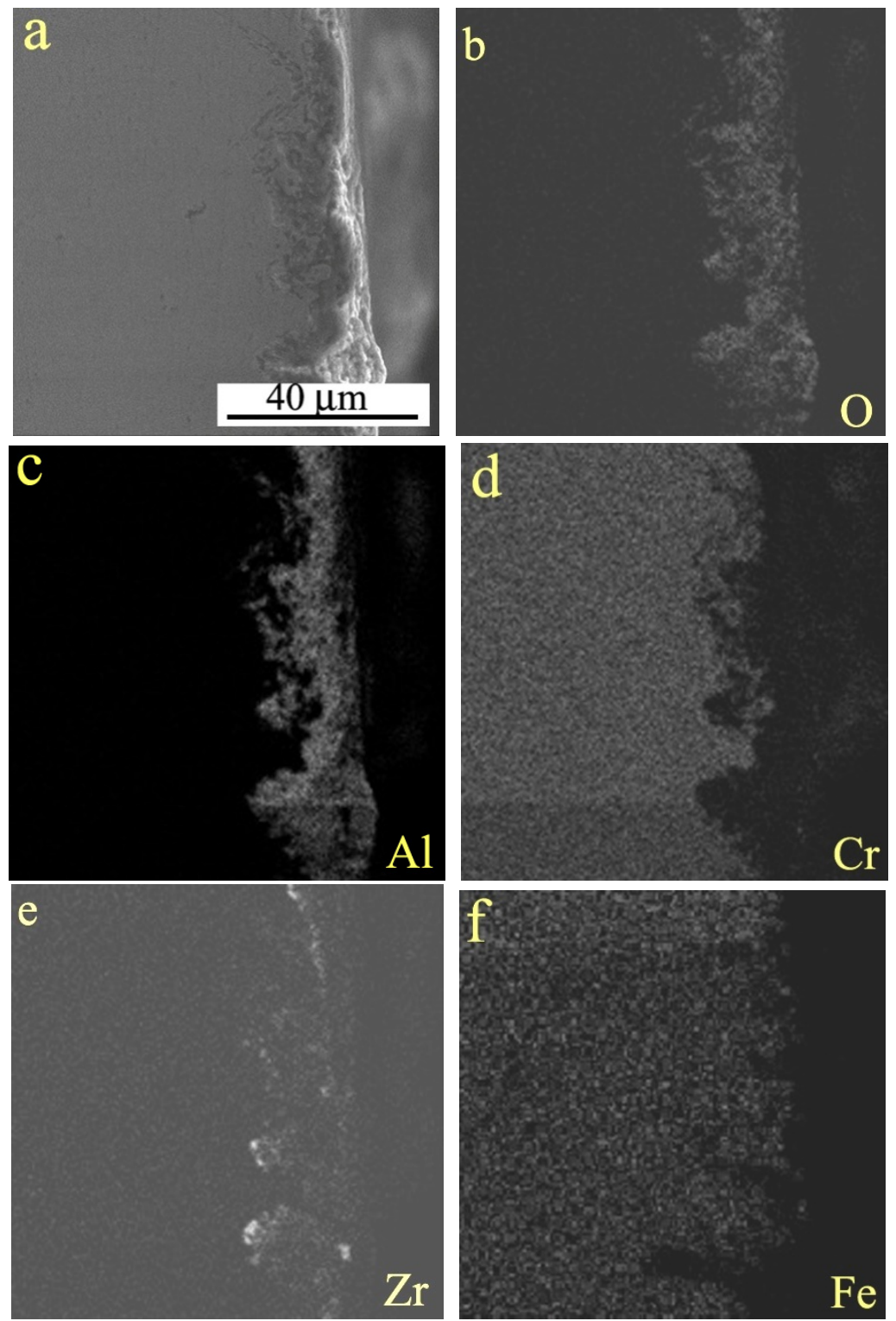

Figure 7. SEM image and elemental mappings of cross-sectional microstructure of sample oxidized at $1280{ }^{\circ} \mathrm{C}$ for 3 h: (a) SEM image, (b) O, (c) Al, (d) Cr, (e) Zr, (f) Fe.

\subsection{Hardness and Wear Performance of Oxide Layers}

The hardness of oxide layers formed at different temperatures was measured using the load of $100 \mathrm{~g}$ for dwell time of $20 \mathrm{~s}$ on a microhardness tester, as shown in Figure 8. The surface hardness increased with increasing oxidation temperature. The reason could be mainly due to the following factors: firstly, the increase of oxides amount in the oxide layer since the content oxygen element increases from $47.95 \%$ at $1220{ }^{\circ} \mathrm{C}$ to $49.85 \%$ at $1340{ }^{\circ} \mathrm{C}$. Secondly, the average thickness of oxide layer increasing with temperature. Thirdly, an increasing amount of fine $\mathrm{ZrO}_{2}$ particles was formed in the oxide layer since a high content of zirconium of $7.75-8.73 \%$ was detected at 1320 and $1340{ }^{\circ} \mathrm{C}$.

The wear weight loss of samples oxidized at different temperatures was measured and plotted against oxidation temperature, as shown in Figure 9. It can be seen that the weight loss is rather high at temperatures of $1220-1260^{\circ} \mathrm{C}$, then it decreases significantly to the minimum at $1280^{\circ} \mathrm{C}$, and finally rises again at $1300^{\circ} \mathrm{C}$ before a slight decrease within the temperature range of 1320 to $1340^{\circ} \mathrm{C}$. 


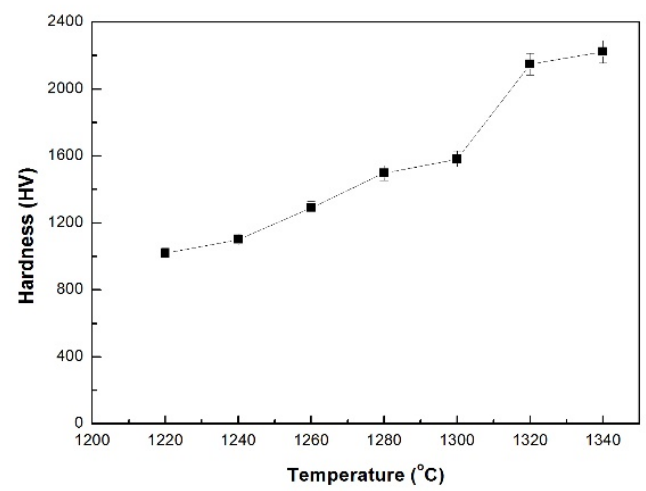

Figure 8. Hardness of oxidation surfaces treated at different temperatures for $3 \mathrm{~h}$.

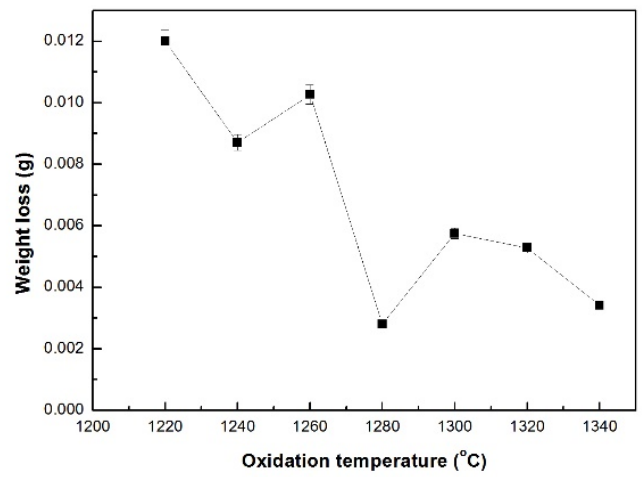

Figure 9. Weight loss of samples oxidized at different temperatures for $3 \mathrm{~h}$.

SEM microphotographs of worn surface morphologies of samples oxidized at different temperatures are shown in Figure 10. At $1240{ }^{\circ} \mathrm{C}$, the oxide layer was almost worn off from the surface, and several small pieces of layers were found around the grooves (Figure 10a). The content of oxygen element was only $8.90 \%$ on the worn surface. Apparently, breakage and spallation of oxide layer and abrasion were the wear mechanisms. These wear features were also presented on the worn surface at $1260{ }^{\circ} \mathrm{C}$ (Figure 10b), and the oxide layer was essentially worn off form the surface. The content of oxygen element on the worn surface was $8.67 \%$. At $1280^{\circ} \mathrm{C}$, the oxide layer was not worn through, and the features of grooves and spallation were absent (Figure 10c). Meanwhile, the content of the O element remained as high as $30.65 \%$ on the worn surface, suggesting that the oxide layer represent a good wear performance. However, at $1300^{\circ} \mathrm{C}$, part of oxide layer was worn through at localized area, and a few severe scratches were present on the worn surface (Figure 10d). Meanwhile, the content of oxygen decreased to $20.77 \%$ on the worn surface. At $1320^{\circ} \mathrm{C}$, surface damage extent was slight as compared with that at $1300{ }^{\circ} \mathrm{C}$, but there still were some spallations of the oxide layer (Figure 10e). At $1340{ }^{\circ} \mathrm{C}$, the worn surface was smooth and surface damage was slight (Figure 10f).

The content of oxygen decreased to $28.34 \%$ on the worn surface, suggesting a good wear performance, but next to that at $1280^{\circ} \mathrm{C}$. Therefore, the optimum treatment parameters for the studied alloy were selected as the oxidation temperature of $1280^{\circ} \mathrm{C}$ and holding time of $3 \mathrm{~h}$. For comparison, KCF material was oxidized using typical oxidation treatment parameters: temperature $1250^{\circ} \mathrm{C}$ and holding time $3 \mathrm{~h}$. The average thickness of the oxide layer was about $7.50 \mu \mathrm{m}$, and the average hardness of the oxide layer was about $1228 \mathrm{HV}$. The weight loss was $0.0024 \mathrm{~g}$ under the sliding condition of $20 \mathrm{~N}$ and $1.0 \mathrm{~m} / \mathrm{s}$. Figure 11 is the photograph of the spot welding location pins of the studied alloy oxidized at the optimum treatment parameters. The practical application of the spot welding location pins of the studied alloy in automotive industry has proved that their performance is comparable to that made of costly material imported from abroad. 

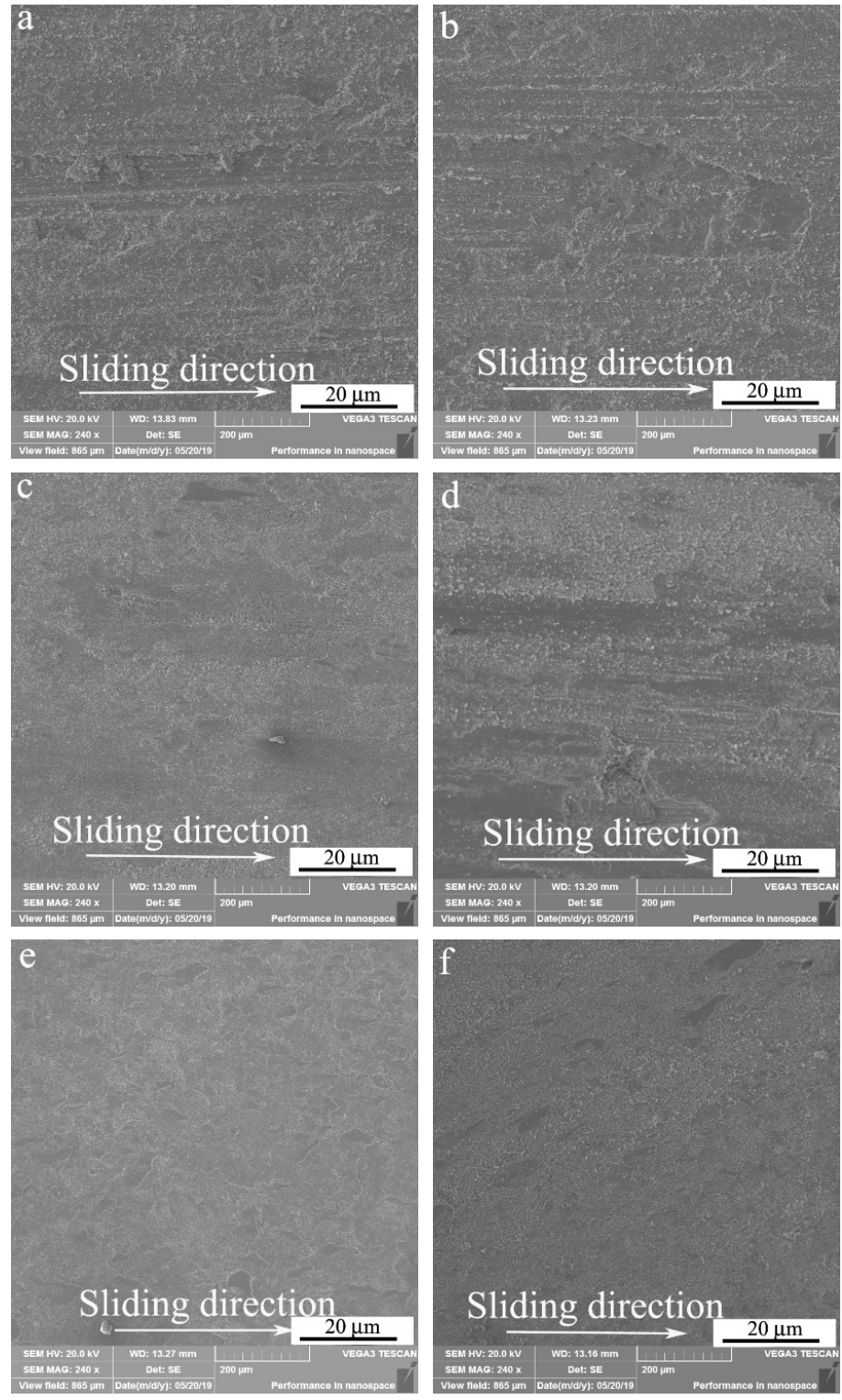

Figure 10. SEM microphotographs of worn surfaces for samples oxidzed at different temperature for $3 \mathrm{~h}:\left(\right.$ a) $1240{ }^{\circ} \mathrm{C}$, (b) $1260{ }^{\circ} \mathrm{C}$, (c) $1280{ }^{\circ} \mathrm{C}$, (d) $1300{ }^{\circ} \mathrm{C}$, (e) $1320^{\circ} \mathrm{C}$, (f) $1340{ }^{\circ} \mathrm{C}$.

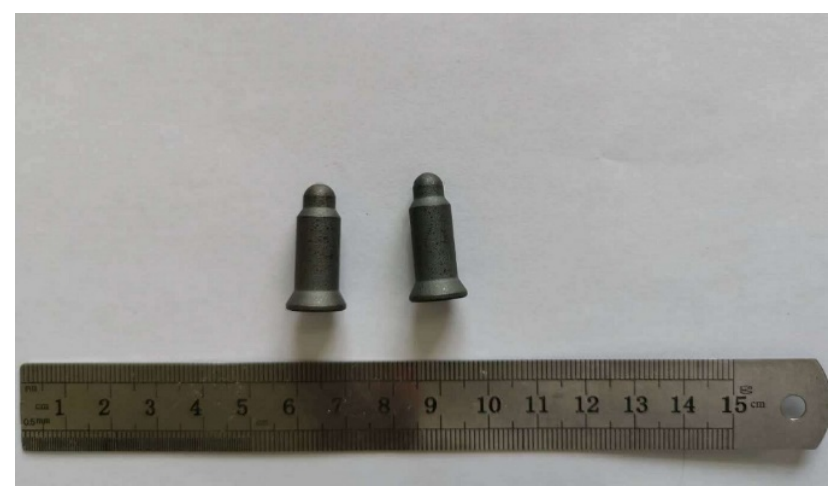

Figure 11. Photograph of spot welding location pins made from the studied alloy. 


\section{Conclusions}

The mass gain of Fe-21.3Cr-3.5Al-0.5Ti-0.4Zr steel presented a stage characteristic with increasing temperature present stage characteristic-i.e., a small increasing at the first stage of $1220-1260{ }^{\circ} \mathrm{C}$, a moderate increasing at the second stage of $1280-1300{ }^{\circ} \mathrm{C}$, a great increasing at the third stage of $1320-1340{ }^{\circ} \mathrm{C}$.

The oxide layer mainly consisted of $\mathrm{Al}_{2} \mathrm{O}_{3}$ phase and a small amount of $\mathrm{ZrO}_{2}$ phase, and the amount of $\mathrm{ZrO}_{2}$ phase increased with increasing oxidation temperature. At temperature of $1340{ }^{\circ} \mathrm{C}$, other phase, i.e., magnetite phases containing Fe element were found to be formed in the oxide layer.

The hardness of oxidation surface increased with temperature within the range of $1220-1340{ }^{\circ} \mathrm{C}$.

The sample oxidized at $1280^{\circ} \mathrm{C}$ exhibited the best wear resistance among the samples treated at temperatures of $1220-1340{ }^{\circ} \mathrm{C}$.

Author Contributions: J.A. conceived and designed the experiments; Y.C., Z.L., and Y.T. performed the oxidation measurements; Y.C. performed SEM analysis; Z.L. and Y.T. analyzed the data; J.A. wrote the paper. All authors have read and agreed to the published version of the manuscript.

Funding: This research received no external funding.

Conflicts of Interest: The authors declare no conflict of interest.

\section{References}

1. Nankung, J.; Kim, M.C.; Park, W.W. Fabrication of Fe-Cr-Al-base alloy strips by melting dragging and their oxidation resistance at elevated temperature. J. Mater. Technol. 2001, 115, 391-395. [CrossRef]

2. Capdevila, C.; Miller, M.K.; Chao, J. Phase separation kinetics in a Fe-Cr-Al alloy. Acta Mater. 2012, 60, 4673-4684. [CrossRef]

3. Bousquet, R.; Fayeulle, D.; Bruyer, E.; Bertrand, F. Effects of yttrium on the oxidation behavior of low sulfur content Fe-Cr-Al alloys for heat resistant wires. Oxid. Met. 2013, 80, 13-24. [CrossRef]

4. Heinonen, M.H.; Kokko, K.; Punkkinen, M.P.J.; Nurmi, E.; Kollar, J.; Vitos, L. Initial oxidation of Fe-Al and Fe-Cr-Al alloys: $\mathrm{Cr}$ as an alumina booster. Oxid. Met. 2011, 76, 331-346. [CrossRef]

5. Kim, S.; Choi, S.; Yun, J.; Kim, B.; Kang, Y.; Lee, K. High temperature oxidation behaviors of Fe-Cr-Al bulk and powder-sintered materials. Met. Mater. 2011, 6, 983-992. [CrossRef]

6. Tortorelli, P.F.; Natesan, K. Critical factors affecting the high temperature corrosion performance of iron aluminides. Mater. Sci. Eng. A 1998, 258, 115-125. [CrossRef]

7. Asteman, H.; Spiegel, M. A comparison of the oxidation behavior of $\mathrm{Al}_{2} \mathrm{O}_{3}$ formers and $\mathrm{Cr}_{2} \mathrm{O}_{3}$ formers at $700{ }^{\circ} \mathrm{C}$-Oxide solid solutions acting as a template for nucleation. Corros. Sci. 2008, 50, 1734-1743. [CrossRef]

8. Gurrappa, I.; Weiinbruch, S.; Naumenko, D.; Quadakkers, W.J. Factors governing breakaway oxidation of FeCrAl-based alloys. Mater. Corros. 2000, 51, 224-235. [CrossRef]

9. Engkvist, J.; Grehk, T.M.; Bexell, U.; Olsson, M. Early stages of oxidation of uncoated and PVD $\mathrm{SiO}_{2}$ coated FeCrAl foils. Surf. Coat. Technol. 2009, 203, 2845-2850. [CrossRef]

10. Hammer, L.; Meier, W.; Blum, V.; Heinz, K. Equilibration processes in surface of the binary alloy Fe-Al. J. Phys. Condens. Matter 2002, 14, 4145-4164. [CrossRef]

11. Niu, Y.; Wang, S.; Gao, F.; Zhang, Z.G.; Gesmundo, F. The nature of the third-element effect in the oxidation of Fe-xCr-3 at.\% Al alloys in 1 atm $\mathrm{O}_{2}$ at $1000{ }^{\circ} \mathrm{C}$. Corros. Sci. 2008, 50, 346-356.

12. Airiiskallio, E.; Nurmi, E.; Heinonen, M.H.; Vayrynen, I.J.; Kokko, K.; Ropo, M.; Punkkinen, M.P.J.; Pitkanen, H.; Alatalo, M.; Kollar, J.; et al. High temperature oxidation of Fe-Al and Fe-Cr-Al alloys: The role of $\mathrm{Cr}$ as a chemically active element. Corros. Sci. 2010, 52, 3394-3404. [CrossRef]

13. Badini, C.; Laurella, F. Oxidation of FeCrAl alloy: Influence of temperature and atmosphere on scale growth rate and mechanism. Surf. Coat. Technol. 2001, 135, 291-298. [CrossRef]

14. Brady, M.P.; Gleeson, B.; Wright, I.G. Alloy design strategies for promoting protective oxide-scale formation. JOM 2000, 52, 16-21. [CrossRef] 
15. Deacon, R.M.; DuPont, J.N.; Kiely, C.J.; Marder, A.R.; Tortorelli, P.F. Evaluation of the corrosion resistance of Fe-Al-Cr alloys in simulated low NOx environments. Part 2: Electroon microprobe analysis and scanning transmission electron microscopy studies. Oxid. Met. 2009, 72, 87-107. [CrossRef]

16. Mizutani, A.; Miura, T.; Fujisawa, M.; Hayashi, S. Influence of Mo on high-temperature oxidation behavior of La- and Zr-added 20 mass\%Cr-6 mass\%Al ferritic stainless steels. Oxid. Met. 2017, 87, 109-124. [CrossRef] 